\title{
Articles
}

Central European Review of Economics \& Finance

Vol. 18, No. 2(2017), pp. 5-18. D0I: 10.24136/ceref.2017.005

Alina $\mathrm{Hyz}^{1}$, Petros Kalandonis ${ }^{2}$, Dimitrios Stavroulakis ${ }^{3}$

\section{MANAGEMENT OF WORKING CAPITAL - THE ACHILLES HEEL OF SMALL AND MEDIUM ENTERPRISES (SMES). THE CASE OF GREECE}

Working capital represents the amount of funds invested in firms' current assets. Optimizing working capital management is a challenge and a necessity for firms especially today due to the demand volatility and limit access to bank credit.

This paper investigates the relationship between working capital management and firms' performance in small and medium enterprises in Greece. The results suggests that an effective working capital management is a necessary component of firm's future growth and profitability.

The analysis used data for a sample of 459 small and medium enterprises for the period from 2008 to 2012. The paper is organized as follows: in the next section we briefly present the problem based on literature review. This is followed by the presentation of research methodology and the data sources used in the analysis. The results are presented and discussed in section three. Last section summarizes the conclusions and presents further opportunities for research.

JEL Classification Codes: G30.

Keywords: SMEs, Working Capital, Profitability, Greece.

\section{Introduction}

The company is an economic system, producing products for sale, providing services against payment, and conducting trade. In general, compa-

\footnotetext{
${ }^{1}$ Professor, Department of Accounting and Finance, Piraeus University of Applied Sciences.

${ }^{2}$ Ass. Professor, Department of Business Administration, Piraeus University of Applied Sciences.

${ }^{3}$ Professor, Department of Accounting and Finance, Piraeus University of Applied Sciences.
} 
nies' finance include all those economic phenomena that are related directly or indirectly to collect and spending of funds for business activities. The profitability of the company as a whole is dependent on a efficient financial management.

Working capital refers to all current assets which means all those assets which can be converted into cash within the short-time period. Working capital has two concepts: gross working capital equals to total current assets and net working capital equals to the excess of current assets over current liabilities. Current assets and current liabilities include three accounts which are of special importance. These accounts include inventories, accounts receivables and accounts payables and represent the areas of the business where managers have the most direct impact (Smith, 1980; Vijay Kumar, 2001; Van Horne and Wachowicz, 2004).

Optimizing working capital management is a challenge and a necessity for firms especially now due to the demand volatility, barriers in access to bank credit (Hyz, 2011), customer payment delays etc. Inefficient working capital management can cause bankruptcy, even if firm's profitability is constantly positive (Kargar and Bluementhal, 1994; Raheman and Nasr, 2007). One of the measure of the efficiency in working capital management is cash conversion cycle, which is the amount of time it takes to turn the accounts receivables and inventories into cash minus the amount of time it takes to pay accounts payables. The longer the cycle is, the longer a business is tying up capital in its working capital earning a return on it. Therefore, companies strive to reduce its cash conversion cycle by minimizing inventories, collecting receivables quicker or sometimes stretching accounts payables. Shortening the cash conversion cycle is the most inexpensive way to grow and to free up cash on one hand and to limit firms' needs for capital market financing.

During the previous years, increasing attention was devoted to effective inventories management. The term "inventory” in manufacturing companies refers to the stockpile of the products a firm is offering for sale and the components that make up the product. The assets which firms store as inventory in anticipation of need are: raw materials, work in progress, finished goods, stores and supplies. The last asset, normally, form a very minor part of total inventory and do not involve significant investment. Excessive inventories are one of the most important problems faced by many companies all over the world. Inventories are engaged primarily funds, usually unproductive freezing high capital of the company. Inventories also cause an increase in costs associated with their maintenance and service. This is especially important today, when the rising cost of operations and increase competition in the 
market eliminate companies which are not effective in reduction of costs. In the frame of efficient working capital management the purpose is to identify the level of inventory which allows for uninterrupted production but reduces the investment in raw materials - and minimizes reordering costs - and hence increases cash flow.

Another components of working capital is accounts receivables and accounts payables. In the frame of debtors management the purpose is to identify the appropriate credit policy, i.e. credit terms which will attract customers, such that any impact on cash flows and the cash conversion cycle will be offset by increased revenues and hence return on capital. Accounts payables can be interpreted as the opposite of accounts receivables. Delaying payments to suppliers can be an inexpensive and flexible source of financing for the firm. On the other hand, late payment of invoices can be very costly if the firm is offered a discount for early payment (Deloof, 2003).

Many researchers investigated the impact of management of working capital and/or its components on firm's profitability. Voulgaris et al. (2000) found that the efficiency of inventory management policy is the main factor of the performance of the Greek firms. They used the financial data of Greek SMEs performance on the basis of a financial ratio analysis using a sample of 143 industrial firms for ten years period. Boute et al. (2007) have studied the financial impact of inventories in Belgian manufacturing industry, wholesale and retail. The results of the regression analysis are not very clear. They find negative coefficients relationship between the inventory ratio and financial performance (ROA), but this coefficients is only significant in $29 \%$ of the cases studied. Also, the analysis of variance shows that companies with a very high inventory ratio have much more chance to be bad financial performers than companies with a very low inventory ratio. Shah and Shin (2007) analyzed sector level data and showed that inventory performance is positively associated with financial performance. Cannon (2008) focuses on assessing the relationship between inventory performance and overall firm performance. He uses firm's annual percentage change in inventory turnover as a measurement for inventory management and return on assets as a measure of performance. He concludes that turnover improvement an average had a slightly negative effect on ROA. Capkun et.al. (2009) find a significant positive correlation between inventory performance and measures of financial performance for firms in manufacturing industries. Shin and Soenen (1998) who studied the relation between Net Trade Cycle (NTC) and firm's performance for a sample consisting of American manufacturing firms for the period of 1974-1995 found strong negative relation and concluded 
that shortening of firm's Net Trade Cycle will increase a shareholders' value. Deloof (2003) found a negative relations between gross operating profit and three parts of the Cash Conversion Cycle (inventories, accounts receivables and accounts payables). His sample consisted of 1009 non-financial Belgium firms for the period 1992-1996. In line with this study is also the research of Garcia-Teruel and Martinez-Solano (2007) which studied Spanish SMEs. The results showed that shortening of firm's number of days accounts receivables and inventories can increase the profitability of the firm. Lazaridis and Trifonidis (2006) which used a sample of 131 companies listed in the Athens Stock Exchange for the period of 2001-2004 found that there is statistical significance between profitability, measured through gross operating profit and the cash conversion cycle. Samiloglu and Demigrunes (2008) analysed a sample consisting of Istanbul Stock Exchange listed manufacturing firms for the period 1998-2007. Empirical findings of the study show that accounts receivables period, inventory period and leverage affect firm profitability negatively, while growth (in sales) affects firm profitability positively.

This paper is an attempt towards understanding the relationship between working capital management and firm's profitability in Greek small and medium enterprises. The reason for the selection of small and medium enterprises was the fact that these companies are the basis of the economies in many countries (Acs and Audretsch, 1990, 1993; Dunlop, 1992; Mulhern, 1995; Hyz, 2006), especially in the Greek economy. We assume that improper management of working capital is one of the reasons behind failures or pure financial performance of many Greek small and medium enterprises. During the period of recession the working capital management get even more importance due to the firm's financial constraints. A comparison of our findings with those from previous research provides important implications for managing companies.

\section{Data Set and Variables}

The data we use was extracted from ICAP database, containing detailed financial reports annuals (income statements and annuals balance sheets) and statistics on Greek companies. This results in a find data set of 459 companies split up over 8 sectors of economic activities according to the European NACE classification scheme. The research covers the period of 2008-2012, which gives the five-year period of observation of financial results of selected companies. 
The criteria used for selection of the companies are two:

1. European Commission criteria for small and medium enterprises, namely:

- headcount $\leq 250$,

- turnover $\leq 50$ million euro,

- total balance sheet $\leq 43$ million euro.

2. Data available for five years continuously. We exclude all firm-year observations without data available on working capital and its components and profitability (sales, cost of goods sold, net income, inventory, accounts receivables, accounts payables, total assets).

Since outlier observations can cause problems we implied standard method of winsorization of the data. For all used variables we replace $5 \%$ of the data by the highest value that is not removed.

The cash conversion cycle is used as a comprehensive measure of working capital management, defined as follows:

$$
C C C=I T+A R T-A P T
$$

where:

CCC - Cash Conversion Cycle,

IT - Inventory turnover expressed by number of days:

or

$$
\frac{\text { Number of days in analyzed period }}{\text { Inventory turnover ratio }}
$$

Average Inventories · Number of days in analyzed period

Cost of goods sold

Inventory turnover ratio is velocity of which total inventories (raw materials, work in process and finished goods) converted into sales. This indicator suggests the ability of company to transform inventories in sales (cash or accounts receivables) in particular period of time. The lower the number of days the better the inventory management.

ART - Accounts Receivables Turnover expressed by number of days:

Number of days in analyzed period

Accounts Receivable turnover ratio

or

Average Accounts Receivable. Number of days in analyzed period 
Accounts Receivable turnover ratio is velocity of which average accounts receivables converted into cash. This indicator suggests the ability of company to transform accounts receivables into cash in particular period of time. The lower the number of days the better the accounts receivables management. While cash-only sales have a ART of zero.

APT - Accounts Payables Turnover expressed by number of days:

Number of days in analyzed period

Accounts Payables turnover ratio

or

Average Accounts Payabless . Number of days in analyzed period

Cost of goods sold

Accounts Payables Turnover ratio is velocity of which average accounts payables are paid. If this can be maximized, the company holds onto cash longer, maximizing its investment potential. The longer is this measure the better is the accounts payables management. While cash-only purchases have a APT of zero.

To measure financial performance, we prefer to use return on assets (ROA) for reasons of data availability and accuracy.

$$
R O A=\frac{\text { Annual Net Income }}{\text { Net Total Assets }}
$$

Return of assets is a measure of firm's performance and is a ratio of firm's reported net income divided by net value of its total assets.

We introduce also two other firm specific variables (internal variables): firm's size and sales growth rate.

The cost of investment in working capital is lower for larger firms compared to smaller and they have larger capacity to extend more trade credits that enable them to have more investment in working capital as compared to smaller firms (Berger et al., 2001; Jordan et al. 1998; Peterson and Rajan, 1997). We use natural logarithm of total assets as a proxy for firm size.

The effect of growth opportunities on working capital can be done via trade credit grant or investment in inventories. Anticipation of the future sales growth might cause to increase the amount of investments in inventories (Gill, 2011; Caballero et al., 2009). The sales growth rate is defined as follows: sales ${ }_{t} /$ sales $_{t-1}$. To avoid having negative values we don't use the

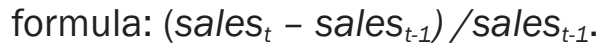


Other researchers used also variables, like „shares and participation to other firms", „financial debt measure" (Lazaridis and Trifonidis, 2006; Deloff, 2003; Garcia-Teruel and Martinez-Solano, 2007). In the case of Greek SMEs the first ratio is less important and the second one is not used due to lack of sufficient data.

For analysing the financial impact we use a regression analysis using profitability measured through return on assets (ROA) as the dependent variable. We use regression analyses based on the following model:

$R O A_{j, t}=\alpha+\beta_{1}$ CCC $_{j, t}+\beta_{2}$ InAssets $_{j, t}+\beta_{3}$ SalesGrowth $_{j, t}+$ Fir $_{k}+$ Year $_{k}+\varepsilon$

$R O A_{j, t}=\alpha+\beta_{1} I T_{j, t}+\beta_{2}$ InAssets $_{j, t}+\beta_{3}$ SalesGrowth $_{j, t}+$ Fir $_{k}+$ Year $_{k}+\varepsilon$

$R O A_{j, t}=\alpha+\beta_{1} A R T_{j, t}+\beta_{2}$ InAssets $_{j, t}+\beta_{3}$ SalesGrowth $_{j, t}+$ Fir $_{k}+$ Year $_{k}+\varepsilon$ $R O A_{j, t}=\alpha+\beta_{1} A P T_{j, t}+\beta_{2}$ InAssets $_{j, t}+\beta_{3}$ SalesGrowth $_{j, t}+$ Fir $_{k}+$ Year $_{k}+\varepsilon$

Here $j$ is representing the firm and $t$ is the time, $\alpha$ is the regression constant, $\beta_{1}, \beta_{2}, \beta_{3}$ are the coefficients of $\operatorname{CCC}_{j, t}$, InAssets ${ }_{j, t}$, SalesGrowth $h_{j, t}$ respectively. $R O A_{j, t}$ is return on assets as a measurement for financial performance of firm $j$ at year $t, C C C_{j, t}$ is cash conversion cycle, $I T_{j, t}$ is inventory turnover in days, $A R T_{j, t}$ is accounts receivables turnover in days, $A P_{j, t}$ is accounts payables in days, InAssets $s_{j, t}$ is the natural log of firm's total asset, SalesGrowth ${ }_{j, t}$ is firm's sales growth. Since ROA can be correlated with factors that are omitted in our dataset, we minimize their effects by using firm-specific control variables and time-specific effects. These control variables can be modelled either as fixed effects or as random effects. To test whether fixed effects are present we employ a Hausman test (Baltagi, et al., 2003). Fir ${ }_{k}$ denotes the firm-specific effects, which are unobservable effects, constant over time but varying across firms, e.g. differences in accounting policy, managerial efficiency and Year $_{k}$ is year- specific fixed effect for year $k$, which are unobservable effects constant across firms but varying over time, e.g. interest rates, $\varepsilon$ indicate the error term for the observations of firm $j$ in the year $t$.

\section{Results and discussion}

Table 1 presents brief overview of the descriptive statistics of the relevant variables of the empirical findings.

In the analysis we focus more on the medians rather than mean due to the fact that means are often influenced by the phenomena of "windows dressing". In other words accounting data are influenced by the tendency of accountants to try to help their clients have a good image. The median of cash conversion cycle for 2.295 observations was 122.28 days (mean was 
183.19 days). The median of total inventory holdings periods were 88.37 days (mean was 159.35 days). Surveyed SMEs receive payment on sales after 104.23 days (mean was 114.78) and paid their creditors in 71.12 days (mean was 88.64 days). High levels of total inventory holdings may be due to the recession in the Greek economy, which did not allow firms to absorb inventories. The situation of Greek economy may also explain the long accounts receivables and payables period. Our financial performance measure show median value of ROA 4.3\% (mean was 5.4\%). In the period analyzed (2008-2012) surveyed SMEs sales declined by $0.9 \%$ annually on average (-0.2\% median). Although we have no data from Greek SMEs from the period before 2008 we can compare above results with those from other studies. We can see that the ratios for Greek SMEs are on the very high level. Taking into account the overall macroeconomic situation of Greece (for more see: Gikas, et al., 2012; Gikas, et al., 2013) this is not consistent with Lamberson (1995) who did argue that the level of working capital would increase during economic boom and decrease during economic slump.

Table 1. Descriptive Statistics

\begin{tabular}{|l|c|c|c|c|c|c|}
\hline \multicolumn{1}{|c|}{ Variable } & Observations & Mean & StDev & Median & Minimum & Maximum \\
\hline CCC & 2295 & 183.19 & 198.04 & 122.28 & -1056.23 & 1386.00 \\
\hline$I T$ & 2295 & 159.35 & 146.78 & 88.37 & 0.00 & 798.69 \\
\hline ART & 2295 & 114.78 & 107.68 & 104.23 & 1.00 & 575.28 \\
\hline APT & 2295 & 88.64 & 110.54 & 71.12 & 0.00 & 567.62 \\
\hline ROA & 2295 & 0.054 & 0.067 & 0.043 & -0.67 & 0.265 \\
\hline SALES GROWTH & 2295 & -0.009 & 0.231 & -0.002 & -0.471 & 0.274 \\
\hline
\end{tabular}

Note: Variables are defined at the section 2: Data Set and Variables.

Table 2 reports the Pearson's correlation matrix for main independent and dependent variables.

According to the results the return on assets $(R O A)$ is negatively correlated with cash convertible cycle (CCC) and all its components (Inventory turnover in days (IT), Accounts receivables turnover in days (ART) and Accounts payables turnover in days (APT)). In all cases the correlation is significant.

It means that the shorter the cash conversion cycle is, the higher the profitability. Also minimizing inventories, collecting account receivables quicker and stretching accounts payable could facilitate a higher profitability. The results of correlation analysis show also significant positive relation between the control variables and the dependent variable. 
Table 2. Correlation matrix for analyzed variables, 2295 firm-year observations

\begin{tabular}{|l|c|c|c|c|c|c|c|}
\hline & $C C C$ & $I T$ & ART & APT & ROA & LNASSETS & $\begin{array}{c}\text { SALES } \\
\text { GROWTH }\end{array}$ \\
\hline CCC & 1 & & & & & & \\
\hline IT & $.756^{* * *}$ & 1 & & & & & \\
\hline ART & $.560^{* * *}$ & $.184^{* *}$ & 1 & & & & \\
\hline APT & $-.324^{* *}$ & $.121^{* *}$ & $.284^{* *}$ & 1 & & & \\
\hline ROA & $-.112^{* *}$ & $-.133^{* *}$ & $-.077^{* *}$ & $-.065^{* *}$ & 1 & & \\
\hline LNASSETS & $.035^{* *}$ & $.117^{* *}$ & $.219^{* *}$ & $.138^{* *}$ & $.003^{* *}$ & 1 & \\
\hline $\begin{array}{l}\text { SALES } \\
\text { GROWTH }\end{array}$ & $.079^{* *}$ & $-.046^{* *}$ & $-.058^{* *}$ & $-.034^{* *}$ & $.073^{* * *}$ & $.009^{* *}$ & 1 \\
\hline
\end{tabular}

Note: Variables are defined at the section 2 „Data Set and Variables”; t-Statistic (*p-value $<0.1 ; * * p$-value $<0.05 ; * * *$ p-value $<0.01)$

Table 3 reports the results of regression analyses for the specification given by equation 1-4 which we used to investigate the impact of working capital management on the profitability of SMEs in Greece. The result of Hausman test implies that the fixed effect estimation is preferable than random effect estimation.

The coefficient of cash conversion cycle variable is negative and statistically significant at least at 5 per cent level of significance, which means that as cash conversion cycle decreasing the firm's profitability increasing. This result is consistent with the results found by Lazaridis and Tryfonidis (2006) and Garcia-Teruel and Martinez-Solano (2007). Although the relationship found by Deloof (2003) is also negative this result is not statistically significant.

In the case of inventory days we found negative and significant relationship. This result is consistent with the results found by Deloof (2003) and Garcia-Teruel and Martinez-Solano (2007). Although the relationship found by Lazaridis and Tryfonidis (2006) is also negative this result is not statistically significant.

There is negative and highly significant relationship between accounts receivables and profitability. This indicates that firms can create profit by keeping the levels of their accounts receivables to a minimum. 
Table 3. Regression Analysis of Determinants of Working Capital Management

\begin{tabular}{|c|c|c|c|c|}
\hline \multirow{2}{*}{ Independent Variables } & \multicolumn{4}{|c|}{ Dependent Variable: ROA } \\
\hline & (1) & (2) & (3) & (4) \\
\hline CCC & $\begin{array}{r}-.0034^{* *} \\
(-5.45)\end{array}$ & - & - & - \\
\hline IT & - & $\begin{array}{c}-.0008^{* *} \\
(-2.33)\end{array}$ & - & - \\
\hline ART & - & - & $\begin{array}{c}-.0025^{\star \star \star} \\
(-6.56)\end{array}$ & - \\
\hline APT & - & - & - & $\begin{array}{c}.0012^{* *} \\
(-6.34)\end{array}$ \\
\hline LNASSETS & $\begin{array}{l}.0054^{* *} \\
(6.98)\end{array}$ & $\begin{array}{l}.0061^{* *} \\
(7.54)\end{array}$ & $\begin{array}{c}0.033^{* *} \\
(7.32)\end{array}$ & $\begin{array}{c}0.436^{* *} \\
(7.11)\end{array}$ \\
\hline SALESGROWTH & $\begin{array}{l}.0241^{* *} \\
(16.05)\end{array}$ & $\begin{array}{l}.0236^{* *} \\
(16.56)\end{array}$ & $\begin{array}{l}.0250^{* *} \\
(17.01)\end{array}$ & $\begin{array}{l}.0246^{* *} \\
(16.78)\end{array}$ \\
\hline Firms Controls & Included & Included & Included & Included \\
\hline Year Controls & Included & Included & Included & Included \\
\hline Adjusted R2 & 0.69 & 0.71 & 0.74 & 0.70 \\
\hline Wu-Hausman Test & 0.00 & 0.00 & 0.00 & 0.00 \\
\hline
\end{tabular}

Note: Variables are defined at the section 2 "Data Set and Variables”; t-Statistic (* p-value $<0.1, * * p$-value $<0.05, * * * p$-value $<0.01$ ). Coefficient estimates are in each cell, and t-values are in parentheses.

According to the results if firm decided to give more trade credit, which means increase of the average days of accounts receivables, the profitability of this firm will decrease by $0.25 \%$ annually. On the other side, the decrease of the average days of accounts receivables will cause ROA's increase by $0.25 \%$. This strong and negative effect of accounts receivables on the firm's profitability may be probably explain by the very high level of Accounts receivables turnover (in days) comparing to other countries, the overall macroeconomic situation in Greece in this period of time and the fact that firms act as lenders to their customers saving in this way the part of their sales. The obtained result is consistent with prior studies: Deloof (2003), Lazaridis and Tryfonidis (2006) and Garcia-Teruel and Martinez-Solano (2007).

We observed negative and significant relationship between return on assets and accounts payables. A negative relation is also found by Lazaridis and Tryfonidis (2006) and Garcia-Teruel and Martinez-Solano (2007). In Greece SMEs due to financial constrains have no easy access to the credits (Hyz, 2011). One of the solution for them is to use accounts payables as a short-term source of financing. 
Based on these results we can conclude that ROA is more sensitive to the changes in accounts receivables. In this case, one approach is to change firm's credit policy or change the structure of customers. But, due to the limit demand in Greece consumers may prefer to shop elsewhere and sales volume can decrease. Sales reduction leads to poor cash inflows. As a result, the firm cannot take advantage of economies of scope and scale and thus, decreasing working capital efficiency even further.

The others variables that have significant effects on firm profitability are Sales Growth and Firms size (measured through the natural logarithm of assets), affecting it positively. This means that any increase in size or sales leads profits to grow. The positive relationship between firm size and working capital management implies that larger firms have longer cash conversion cycle. The positive relationship between firms growth and ROA implies that the anticipation of the future sales growth causes increase of investments in inventories. Moreover, increasing sales via expanding trade credit to the customers make it necessary to have more investment in working capital (Petersen and Rajan, 1997).

\section{Conclusion}

The study is an attempt to investigate the relationship between the working capital management of small and medium enterprises in Greece and its profitability. Working capital management means managing it and its components efficiently and effectively for ensuring firm's growth and profitability. The ICAP database has been used for collecting the financial data of SMEs sample for five years from 2008 to 2012 . Proper working capital management will improve the management efficiency, which translates into profit growth. It may be obtain by 1 increase reliability of business processes in the company guaranteed by a reasonable level and structure of working capital components 2 increasing the speed of movement of backup, which leads to the liberation of funds (capital) involved in working capital components 3 lowering costs by reducing working capital components level.

After the comparison of results with other studies we can see that, due to very high ratios of working capital management in Greek small and medium enterprises, there is a big margin of profitability's improvement. At the optimal level of working capital firms can establish desired trade-off between liquidity and profitability and as a result firm's value (Hill et al., 2010; Smith, 1980; Nasr, 2007). This trade-off is a balance between risk and return. 
Determining the important factors affecting working capital management would make managers able to manage working capital efficiently and effectively. In every case there is a need of individual attempt to the problem: first of all, the managers should to understand the necessity of working capital control, next they have to understand working capital influence on the profitability and finally they have to find the optimum level of working capital components according to the internal and external firm's environment with the main criterion firm's survival via growth.

Future studies may include comparison with other countries during the crisis (and before or after the crisis) and provide greater insight in the task of explaining the relationship between working capital management and profitability. Another one, exciting challenge for future research is to include cross sectional analysis. Finally, a research agenda of mixed methods would be useful.

\section{References:}

Acs Z.J., Audretsch D.B. (1990). The Economics of Small-Firms: A European Challenge, Kluwer Academic Publishers, Dordrecht.

Acs Z.J., Audretsch D.B. (1993). Small Firms and Entrepreneurship: An EastWest Perspective, Cambridge University Press, Cambridge.

Baltagi B., Bresson G., Pirotte A. (2003). Fixed Effects, Random Effects or Hausman-Taylor? A pretest estimator, Economic Letters, Vol. 79.

Berger A., Klapper F., Udell. G. (2001). The Ability of Banks to Lend to Informational Opaque Small Business, Journal of Banking and Finance, Vol. 25.

Boute N.R., Lambrecht M.R., Lambrechts O., Sterckx P. (2007). An Analysis of inventory turnover in the Belgian manufacturing industry, wholesale and retail and the financial impact on inventory reduction, Department of Decision Sciences and Information Management (KBI), Faculty of Economics and Applied Economics, Katholieke Universiteit Leuven.

Brożek K., Kogut J. (2016). Econometric analysis of selected factors of innovative companies activity in the polish economy, Central European Review of Economics \& Finance, No. 6, Vol. 16.

Bukowski S.I., Hyz A.B. (2015). Integration of Greek and polish equity markets with the euro area equity market. Comparative analysis, Central European Review of Economics \& Finance, No. 3, Vol. 9.

Caballero J., Teruel G., Solano P. (2009). Working Capital Management in SMEs. Accounting and Finance, No. 3, Vol. 50. 
Cannon A.R. (2008). Inventory Improvement and Financial Performance, International Journal of Production Economics, Vol. 115.

Capkun V., Hameri A.P., Weiss L.A. (2009). On the relationship between inventory and financial performance in manufacturing companies, International Journal of Operations \& Production Management, Vol. 29, Iss. 8.

Deloof M. (2003). Does Working Capital Management Affect Profitability of Belgian Firms?, Journal of Business Finance \& Accounting, No. 3-4, Vol. 30.

Dunlop W. (1992). Small vs. Large Firms in Australian Manufacturing, Small Business Economics, No. 1, Vol 4.

García-Teruel P.J., Martínez-Solano P. (2007). Effects of working capital management on SME profitability, International Journal of Managerial Finance, Iss. 2, Vol. 3.

Gikas G., Hyz A., Tagkas P. (2013). The Experience of Greece from its participation in the Eurozone, Management Insight. The Journal of Incisive Analysers, No 1, Vol. IX.

Gikas G., Hyz A., Tangkas P. (2012). Global Financial Crisis and Greek Debt Crisis, Acta Universitatis Lodzendzis, Folia Oiconomika 273.

Gill A. (2011). Factors that Influenc Working Capital Requirement in Canada, Economics and Finance Review, Vol. 1(3): 30-40, May.

Hyz A. (2006). The Development of Entrepreneurship and Small Business in Poland, Festschrift in honour of professor Maria Negreponti - Delivani, University of Macedonia, Economic and Social Sciences, Thessaloniki.

Hyz A. (2011). Small and Medium Enterprises (SMEs) in Greece - barriers in access to Banking Services. Empirical Investigation, International Journal of Management and Technology (IJMT), Vol. 1.

Jordan J., Lowe J., Taylo P. (1998). Strategy and Financial Policy in UK Small Firms, Journal of Business Finance and Accounting, Vol. 25.

Kargar J., Blumenthal R.A. (1994). Leverage impact of working capital in small businesses, TMA Journal, No. 6, Vol. 14.

Lazaridis I., Tryfonidis D. (2006). The relationship between working capital management and profitability of listed companies in the Athens Stock Exchange, Journal of Financial Management and Analysis, No. 1, Vol. 19.

Mulhern A. (1995). The SME sector in Europe: a broad perspective, Journal of Small Business Management, No. 3, Vol. 33.

Peterson M., Rajan R. (1997). Trade Credit: Theories and Evidence. Review of Financial Studies, No. 3, Vol. 10. 
Raheman A., Nasr M. (2007). Working Capital Management And Profitability Case Of Pakistani Firms, International Review of Business Research Papers, No. 1, Vol. 3.

Samiloglu F., Demigunes K. (2008). The Effect of Working Capital Managemnet on Firm Profitability: Evidence from Turkey, The International Journal of Applied Economics and Finance No. 2(1).

Shah R., Shin H. (2007). Relationships Among Information Technology, Inventory, and Profitability: An Investigation of Level Invariance Using Sector Level Data, Journal of Operations Management, Vol. 25.

Shin H.H., Soenen L. (1998). Efficiency of working capital and corporate profitability, Financial Practice and Education, No. 2, Vol. 8.

Smith K. (1980). Profitability Versus Liquidity Tradeoffs In Working Capital Management, In Readings On The Management Of Working Capital. New York: St. Paul, West Publishing Company.

Van-Horne J.C., Wachowicz, J.M. (2004), Fundamentals of financial management, Prentice Hall Publishers, 2004, $12^{\text {th }}$ edition.

Vijay Kumar A. (2001). Working Capital Management. A Comparative Study, Northern Book Centre, New Delhi.

Voulgari F., Doumptos M., Zapounidis C. (2000). On the evolution of Greek industrial SME's performance via multicriteria analysis of financial ratios, Small Business Economics, Vol. 15. 